Original Research Paper

\title{
Pengenalan dan Pengaplikasian Microsoft Word dan Microsoft PowerPoint di SMA Negeri 1 Praya Tengah
}

\author{
Nurul Ahadia ${ }^{1 *}$, M. Zulmuhibban ${ }^{2}$, Cahayatul Aulia $^{3}$, Nindi Claudia ${ }^{4}$, Nisratul Apriyani ${ }^{5}$, Ririn Widiawati ${ }^{4}$, \\ Widya Anggreni ${ }^{4}$, Yuyun Ningsiati ${ }^{6}$, I Gde Mertha ${ }^{1}$

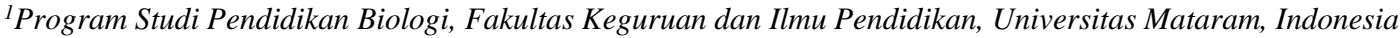 \\ ${ }^{2}$ Program Studi Pendidikan Sosiologi, Fakultas Keguruan dan Ilmu Pendidikan, Universitas Mataram, Indonesia \\ ${ }^{3}$ Program Studi Pendidikan Guru Sekolah Dasar, Fakultas Keguruan dan Ilmu Pendidikan, Universitas Mataram, Indonesia \\ ${ }^{4}$ Program Studi Pendidikan Fisika, Fakultas Keguruan dan Ilmu Pendidikan, Universitas Mataram, Indonesia \\ ${ }^{5}$ Program Studi Pendidikan Bahasa dan Sastra Indonesia, Fakultas Keguruan dan Ilmu Pendidikan, Universitas Mataram, \\ Indonesia \\ ${ }^{6}$ Program Studi Pendidikan PPKn, Fakultas Keguruan dan Ilmu Pendidikan, Universitas Mataram, Indonesia
}

https://doi.org/10.29303/jpmpi.v3i2.601

Sitasi: Ahadia, N., Zulmuhibban, M., Aulia, C., Claudia, N., Apriyani, N., Widiawati, Anggreni, W., Ningsiati, Y., \& Mertha, I. G. (2021). Pengenalan dan Pengaplikasian Microsoft Word dan Microsoft PowerPoint di SMA Negeri 1 Praya Tengah. Jurnal Pengabdian Magister Pendidikan IPA, 4(1)

\section{Article history}

Received: 05 Desember 2020

Revised: 30 Desember 2020

Accepted: 25 Januari 2021

*Corresponding Author: Nurul Ahadia, Program Studi Pendidikan Biologi, Fakultas Keguruan dan Ilmu Pendidikan, Universitas Mataram, Mataram, Indonesia;

Email:

nurulahadia2@gmail.com

\begin{abstract}
Komputer merupakan salah satu media elektronik yang banyak digunakan untuk memudahkan manusia mengelola data dan menyimpan informasi (data storage) dengan praktis dan efisien. Pada era serba digital saat ini, teknologi informasi dan komunikasi berbasis komputer telah mempengauhi berbagai aspek kehidupan termasuk pendidikan tidak dapat disangkal lagi. Kegiatan pengabdian ini bertujuan untuk memberi pendampingan kepada peserta didik di SMA Negeri 1 Praya Tengah, Kabupaten Lombok Tengah dalam mengaplikasikan Microsoft Word dan Microsoft PowerPoint. Dengan adanya kegiatan ini diharapkan dapat mempermudah peserta didik dalam melakukan pengolahan kata dan pembuatan media presentasi yang berguna untuk mempermudah proses pembelajaran. Metode yang digunakan dalam upaya mencapai target atau tujuan yang telah direncanakan adalah ceramah, praktek (unjuk kerja) dan tanya jawab. Peserta pelatihan dibagi dalam kelompok. Setiap kelompok didampingi oleh seorang mentor. Untuk mengetahui keberhasilan program kegiatan yang telah dilaksanakan dilakukan evaluasi. Evaluasi dilakukan dengan cara memberikan ujian praktek untuk mengetahui tingkat pemahaman peserta didik terkait materi dan pelatihan yang telah diberikan. Kesimpulan dari kegiatan ini bahwa pengabdian telah berhasil meningkatkan pengetahuan peserta didik dalam pengaplikasian Microsoft Word dan PowerPoint. Peserta didik di SMA 1 Praya Tengah merasa terbantu dengan adanya pelatihan yang dilakukan sehingga mereka dapat menggunakan komputer atau laptop dalam mengerjakan tugas sekolah dengan baik, seperti membuat makalah dan power point untuk memudahkan dalam kegiatan presentasi. Peserta didik memberikan respon yang sangat positif terhadap kegiatan yang dilakukan dan menilai kegiatan ini sangat bermanfaat.
\end{abstract}

Keywords: Microsoft Word; Microsoft PowerPoint; Komputer; Era Digital. 


\section{Pendahuluan}

Penguasaan teknologi informasi dan komunikasi (TIK) merupakan kebutuhan dalam menghadapi era globalisasi. Di era serba digital saat ini, manusia dituntut untuk dapat mengoperasikan komputer seperti laptop, komputer CPU, handphone, smartphone, dan sebagainya. Komputer merupakan salah satu media elektronik yang banyak digunakan, banyak hal yang dapat dilakukan dengan komputer, seperti memudahkan manusia mengelola data, menyimpan informasi (data storage) dengan praktis dan efisien (Permana \& Mahameruaji, 2019). Selain itu, keterampilan dalam penggunaan komputer atau literasi digital juga sangat menentukan keberhasilan seseorang dalam pendidikan. Jika dilihat dari segi media pembelajaran, banyak media pembelajaran yang bisa dijalankan melalui penggunaan komputer dengan mengimplementasikan aplikasi tertentu (Astawa, 2019).

Pengetahuan akan teknologi informasi dan komunikasi berbasis komputer saat ini sangat dibutuhkan oleh masyarakat baik orang dewasa maupun remaja atau anak-anak yang saat ini menjadi peserta didik. Khususnya pada peserta didik, peran TIK dalam berbagai aspek kehidupan termasuk pendidikan tidak dapat disangkal lagi. Kehadiran TIK dalam pembelajaran tidak memberikan pilihan lain kecuali turut serta dalam memanfaatkannya (Widyastono, 2017). Apalagi pada Era New Normal saat ini, anak-anak yang terdampak pandemi COVID-19 melaksanakan pembelajaran berbasis Less Contact Community alias lebih banyak daring, sehingga tidak ada pilihan bagi guru dan siswa untuk memanfaatkan TIK dalam kegiatan edukasi, baik kegiatan tatap muka maupun penugasan.

Salah satu aplikasi dalam komputer yang banyak dimanfaatkan untuk pembuatan tugas di sekolah adalah Microsoft Word (Sari dkk, 2020) dan Microsoft PowerPoint (Maryatun, 2015). Microsoft Word atau Microsoft Office Word adalah perangkat lunak pengolah kata (word processor) andalan Microsoft. Microsoft Word adalah program pengolah kata pada komputer yang pertama kali diperkenalkan pada tahun 1983 oleh raksasa teknologi Microsoft. Sejak awal diciptakan, produk ini telah mengalami pengembangan dalam berbagai versi. Microsoft Word memungkinkan penggunanya mengkombinasikan tidak hanya berupa kata, tetapi juga gambar dan diagram (Purnomo, 2011). Microsoft PowerPoint adalah sebuah program komputer untuk presentasi yang dikembangkan oleh Microsoft di dalam paket aplikasi kantoran mereka. Aplikasi ini sangat banyak digunakan, apalagi oleh kalangan perkantoran dan pebisnis, para pendidik, peserta didik, dan trainer. PowerPoint merupakan salah satu program aplikasi dari Microsoft yang dapat digunakan untuk melakukan presentasi, baik untuk melakukan sebuah rapat maupun perencanaan kegiatan lain termasuk digunakan sebagai media pembelajaran di sekolah Mardi dkk. (2007) dalam Anonim, (2017).

Aplikasi Microsoft Word dan Microsoft PowerPoint memberikan kemudahan bagi peserta didik dalam menyelesaikan tugas. Tulisan spreadsheet pada Microsoft Excel dapat dipindahkan dengan menempel (paste) spreadsheet tersebut menjadi tabel di Word. Microsoft Word juga dapat dihubungkan dengan aplikasi Microsoft lainnya seperti PowerPoint, OneNote, Outlook. Kelebihan yang dimiliki oleh Microsoft Word ini membantu mempersingkat waktu dalam mengerjakan tugas. Kelebihan lain Microsoft Word adalah membantu menyempurnakan tulisan pada dokumen (Wijaya, 2020). Dengan tingkat kemudahan yang relatif tinggi, serta diimbangi dengan hasil yang maksimal, Microsoft PowerPoint sangat membantu tugas presenter dalam menyampaikan informasi. Kelebihan lain aplikasi ini adalah memberikan efek visual, mudah dibagikan, dilengkapi banyak tools, dan bisa digunakan untuk kolaborasi dengan tim/kelompok (Anonim, 2020).

Kegiatan pengabdian ini bertujuan untuk memberi pendampingan kepada peserta didik di SMA Negeri 1 Praya Tengah, Kabupaten Lombok Tengah dalam mengaplikasikan Microsoft Word dan Microsoft PowerPoint. Dengan adanya kegiatan ini diharapkan dapat mempermudah peserta didik dalam melakukan pengolahan kata dan pembuatan media presentasi yang berguna untuk mempermudah proses pembelajaran.

\section{Metode}

Pelatihan dilakukan sebanyak empat kali pertemuan, setiap hari Kamis, yaitu tanggal 3, 10, 17, dan 24 Desember 2020 di SMA Negeri 1 Praya Tengah, Kabupaten Lombok Tengah, Provinsi Nusa 
Tenggara Barat. Materi pelatihan mencakup pentingnya penguasaan komputer dalam TIK, dasar teori Microsoft Word, pengaplikasian Microsoft Word dalam membuat laporan, dan pengaplikasian Microsoft PowerPoint dalam pembuatan slide presentasi.

Metode yang digunakan dalam upaya mencapai target atau tujuan yang telah direncanakan adalah ceramah, praktek (unjuk kerja) dan tanya jawab. Peserta pelatihan dibagi dalam kelompok. Setiap kelompok didampingi oleh seorang mentor.

Untuk mengetahui keberhasilan program kegiatan yang telah dilaksanakan dilakukan evaluasi. Evaluasi dilakukan dengan cara memberikan ujian praktek untuk mengetahui tingkat pemahaman peserta didik terkait materi dan pelatihan yang telah diberikan.

\section{Hasil dan Pembahasan}

Kegiatan pelatihan Microsoft Office ini dihadiri oleh 50 orang peserta didik yang semuanya adalah siswa SMA Negeri 1 Praya Tengah. Pelatihan ini dimulai dengan sesi perkenalan antara pemateri dengan peserta didik serta penyampaian tujuan pengabdian. Selain itu, pada pertemuan pertama ini peserta didik juga diberikan motivasi akan pentingnya memiliki wawasan dan pengetahuan ilmu teknologi dan komunikasi.

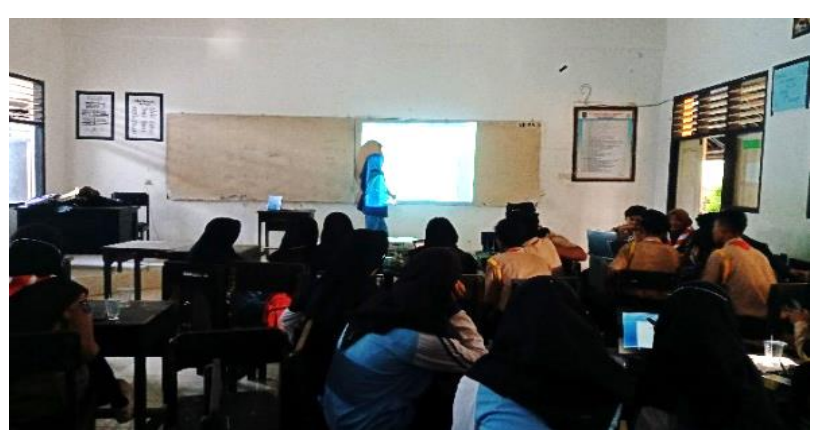

Gambar 1. Penyampaian Materi Aplikasi Microsoft Word.

Pada pertemuan kedua, peserta didik diberikan teori tentang Microsoft Word. Materi yang disampaikan adalah tampilan, menu serta fungsi icon-icon dalam Microsoft word dan cara penggunaanya.

Setelah peserta didik memahami materi tentang Microsoft Word beserta cara penggunaanya, maka pada pertemuan ketiga diberikan praktek cara membuat makalah yang benar, membuat paragraf, membuat tabel, membuat tulisan dengan berbagai variasi, memasukkan gambar, membuat daftar isi secara praktis dan manual, membuat penomoran pada makalah, serta cara membuat daftar pustaka pada tulisan ilmiah dan menyimpan dokumen.

Pada pertemuan keempat, peserta didik diberikan teori sekaligus cara penggunaan Microsoft PowerPoint. Kegiatan praktek pada pertemuan ini adalah membuat slide presentasi yang simple dan menarik dengan memanfaatkan menu-menu yang ada pada aplikasi tersebut, seperti cara menggunakan menu design, transition, serta animation. Presentasi PowerPoint dapat terdiri dari teks, grafik, objek gambar, clipart, movie, suara dan objek yang dibuat program lain.

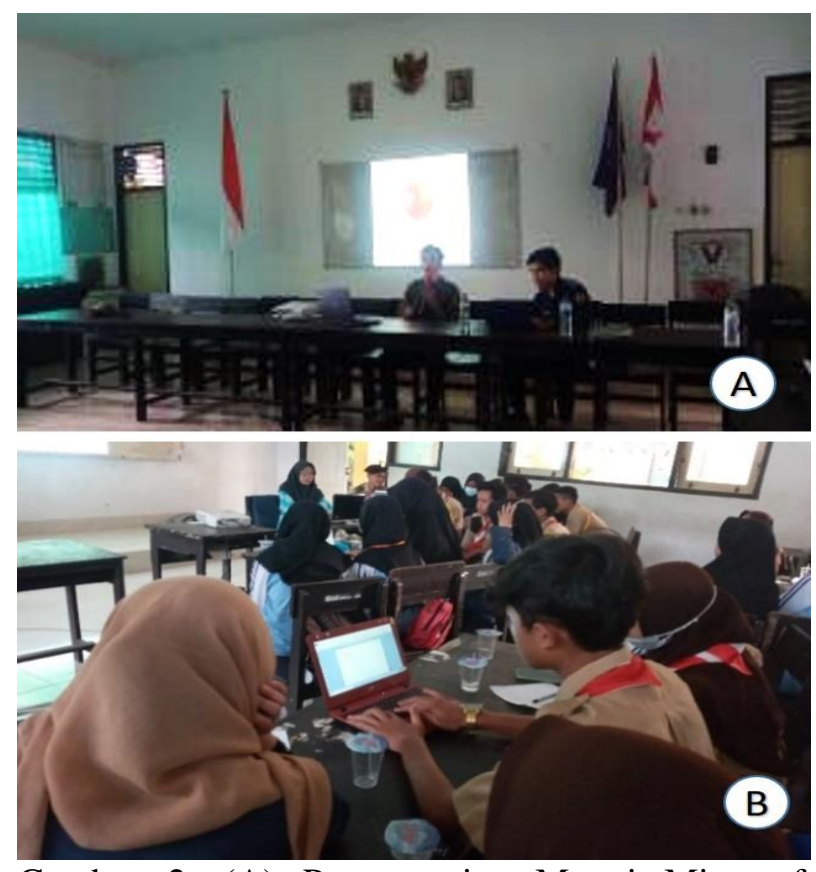

Gambar 2. (A) Penyampaian Materi Microsoft PowerPoint. (B) Pelatihan Pengaplikasian Microsoft Word.

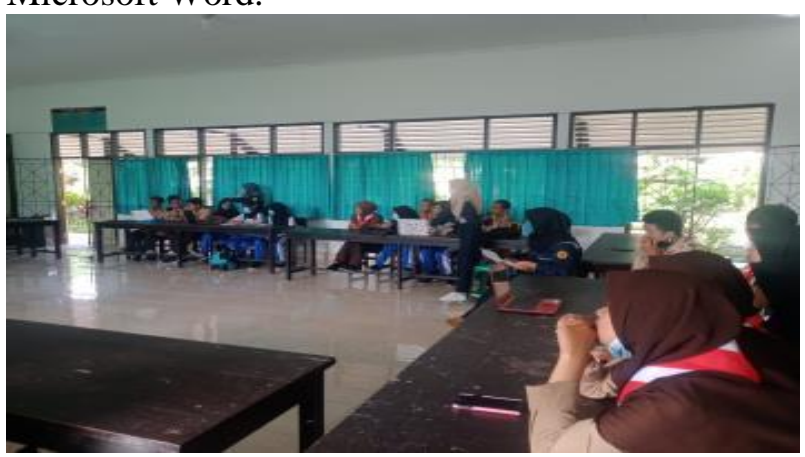

Gambar 3. Pelatihan Pengaplikasian Microsoft PowerPoint. 
Berdasarkan kegiatan pengabdian yang telah dilaksanakan dan evaluasi, pengenalan dan pengaplikasian Microsoft Word dan Microsoft PowerPoint ini secara garis besar telah berjalan sesuai target yang diharapkan. Kegiatan ternyata cukup mendapatkan respon yang baik dari peserta didik di SMAN 1 Praya Tengah, hal ini dapat dilihat dari antusias peserta didik dalam mengikuti kegiatan. Hasil pemantauan selama kegiatan menunjukkan bahwa peserta didik menunjukkan keaktifan dalam mengikuti pelatihan. Peserta didik aktif bertanya dan menanggapi materi yang disampaikan oleh pemateri ataupun tutor. Hasil pengabdian yang terlihat jelas adalah meningkatnya pengetahuan peserta didik terkait program aplikasi Microsoft Word dan Microsoft PowerPoint. Hampir seluruh peserta didik setelah mendapatkan pelatihan, kemampuan dan keterampilan dalam menggunakan fitur-fitur pada perangkat lunak Microsoft Word dan PowerPoint meningkat. Hal ini diperkuat hasil evaluasi bahwa sebanyak 85 persen peserta dapat menyelesaikan tugas dan soal ujian dengan baik.

\section{Kesimpulan}

Berdasarkan hasil yang diperoleh dapat disimpulkan bahwa kegiatan pengabdian telah berhasil meningkatkan pengetahuan peserta didik dalam pengaplikasian Microsoft Word dan PowerPoint. Peserta didik di SMA 1 Praya Tengah merasa terbantu dengan adanya pelatihan yang dilakukan sehingga mereka dapat menggunakan komputer atau laptop dalam mengerjakan tugas sekolah dengan baik, seperti membuat makalah dan power point untuk memudahkan dalam kegiatan presentasi. Peserta didik memberikan respon yang sangat positif terhadap kegiatan yang dilakukan dan menilai kegiatan ini sangat bermanfaat.

\section{Ucapan Terima Kasih}

Terima kasih disampaikan kepada Lembaga Penelitian dan Pengabdian Kepada Masyarakat (LPPM) Universitas Mataram atas dukungan moral selama kami menjalankan program pengabdian masyarakat melalui agenda Kuliah Kerja Nyata (KKN ERA NEW NORMAL) tahun akademik 20202021. Atas partisipasi aktif peserta didik di SMA Negeri 1 Praya Tengah dalam pelaksanaan program
KKN ini diucapkan terimakasih dan penghargaan yang tinggi.

\section{Daftar Pustaka}

Anonim, 2017. Pengertian Power Point Menurut Para Ahli. rangkumanpustaka.com.

Anonim. 2020. Mengungkap Kelebihan Microsoft PowerPoint. kreasipresentasi.com.

Astawa, N. L. P. N. S. P. 2019. Buku Cerita Fabel Berbasis Pendidikan Karakter Untuk Siswa Sekolah Dasar Kelas Tinggi. Jurnal Lentera Pendidikan Pusat Penelitian LPPM UM Metro 4(2): 126-143.

Maryatun. 2015. Pengaruh Penggunaan Media Program Microsoft PowerPoint Terhadap Hasil Belajar Strategi Promosi Pemasaran Mahasiswa Semester 2 Program Studi Pendidikan Ekonomi Universitas Muhammadiyah Metro Tahun Ajaran 2014/2015. JURNAL PROMOSI Jurnal Pendidikan Ekonomi UM Metro 3(1): 1-14.

Permana, R. S. M. dan J.N. Mahameruaji. 2019. Strategi Pemanfaatan Media Baru Net. TV. Jurnal Studi Komunikasi dan Media 23 (1): 21-36.

Purnomo, C. H. 2011. Panduan belajar Otodidak Microsoft Office Word 2010. Mediakita. Jakarta.

Sari, R., A. Fitriyani dan R.D. Prabandari. 2020. Optimalisasi Penggunaan MS. Word dan MS. Excel Pada Siswa SMP PGRI Astra Insani Bekasi. Jurnal ABDIMAS (Pengabdian kepada Masyarakat) 3(2): 95 104.

Widyastono, H. 2017. Pemanfaatan Teknologi Informasi dan Komunikasi pada Sekolah Menengah Pertama Negeri Akreditasi A di Provinsi Jawa Timur. Kwangsan 5(1): 21 38.

Wijaya, M. 2020. Kelebihan dan Kekurangan Microsoft Word. nitrotekno.com 